\title{
THE PROBLEMATICS ON IMPLEMENTATION OF LAW NUMBER 23 YEAR 2011 CONCERNING ZAKAT MANAGEMENT AT BAZNAS LUBUK LINGGAU CITY
}

\author{
Aneka Rahma ${ }^{1} \&$ Badrun Tamam ${ }^{2}$ \\ 1,2 Faculty of Sharia IAIN Bengkulu \\ J. Raden Fatah Pagar Dewa Kota Bengkulu \\ Email: ${ }^{1}$ anekarahma91@gmail.com; ${ }^{2}$ badruntaman.ofc@gmail.com
}

\begin{abstract}
This study aims to explain the problems in implementing Article 3 of Law Number 23 Year 2011 concerning Zakat Management in BAZNAS, Lubuklinggau City, South Sumatra. This is qualitative field and library research. The data collection techniques are observation, interview and documentation. The issues are how the efforts of Baznas Lubuk Linggau in implementing Law Number 23 Year 2011 and what are the problems in its implementation. The results show that Baznas Lubuk Linggau strives to empower zakat funds optimally through the Smart Lubuklinggau Program, Lubuk linggau Peduli, Lubuk linggau Taqwa, Lubuk linggau Sehat, Lubuk linggau Makmur, and Lubuk linggau Amil, as well as proposing a Mayor Regulation on zakat. Meanwhile, the problem of implementation are: the manager does not yet have compelling authority, the institution cannot be controlled by muzakki, supervision of implementation of planned programs is not optimal; lack of awareness of public participation, and the mindset of the people who still think that the zakat funds they receive is a provision and become their right that do not need to be accounted.
\end{abstract}

Keywords: effectiveness; zakat management; poverty; Lubuklinggau

\begin{abstract}
Abstrak: Penelitian ini bertujuan untuk menjelaskan problematika pelaksanaan pasal 3 Undang-undang Nomor 23 Tahun 2011 tentang Pengelolaan Zakat di BAZNAS kota Lubuklinggau Sumatera Selatan. Jenis penelitiannya adalah kualitatif lapangan dan pustaka. Teknik pengumpulan data yang digunakan adalah observasi, wawancara dan dokumentasi. Rumusan masalahnya adalah bagaimana upaya Baznas Lubuk Linggau dalam mengimplementasikan Undang-Undang Nomor 23 Tahun 2011 dan bagaimana problematika pelaksanaannya. Hasil penelitian menunjukkan bahwa Baznas Lubuk Linggau berupaya dengan melakukan pemberdayaan dana zakat secara optimal melalui Program Lubuklinggau Cerdas, Lubuk Linggau Peduli, Lubuk Linggu Taqwa, Lubuk Linggau Sehat, Lubuk Linggau Makmur, dan Lubuk Linggau Amil, serta mengajukan Peraturan Walikota tentang zakat. Sedangkan problematika pelaksanaannya adalah pengelola belum memiliki kewenangan yang bersifat memaksa, lembaga tidak bisa dikontrol oleh muzakki, pengawasan dalam pelaksanaan program yang direncanakan belum optimal, kurangnya kesadaran partisipasi masyarakat, dan pola pikir masyarakat yang masih menganggap dana zakat yang diterimanya adalah suatu rezeki dan menjadi hak mereka yang tidak perlu dipertanggungjawabkan
\end{abstract}

Kata kunci: efektivitas; pengelolaan zakat; kemiskinan; Lubuklinggau

\section{Introduction}

Paying zakat is one of the five pillars of Islam that every capable Muslim must carry out. After the nisab and haul of his assets in the form of agricultural products, livestock and wealth in the form of gold, silver and various other forms of work has accumulated. The obligation of zakat is stated in the Qur'an after the command to establish prayers and the third order in the pillars of Islam, 
automatically becomes an absolute part of one's Islam. Normatively, the obligation of zakat is not only vertical in dimension (hablum min Allah), but also has a horizontal dimension (hablum min al-nas). ${ }^{1}$

In the hablum min Allah dimension, zakat is a manifestation of a servant's obedience to Allah. Whereas in the hablum min alnas dimension, zakat can generate and increase solidarity commitment among fellow Muslims. In this context, zakat is one of the components that becomes an instrument of social justice and human solidarity, in order to eliminate social injustice. ${ }^{2}$

Morally, zakat is able to erode negative traits, such as greed for property (the tendency to monopolize property excessively). Meanwhile, socially, zakat serves as a powerful tool to reduce poverty in the midst of society ${ }^{3}$ and at the same time it will also be able to make rich people aware of their social responsibility to others, so that a healthy wealth distribution process occurs in the midst of society. As a result, the gap and social jealousy between the rich and the poor can be suppressed and minimized. ${ }^{4}$ Thus, zakat has a very strategic value in community empowerment efforts, especially those who are weak, needy and poor. $^{5}$

\footnotetext{
${ }^{1}$ Faisal, "Sejarah Pengelolaan Zakat di Dunia Muslim dan Indonesia", Jurnal Analisis, Vol. XI, No. 2, December 2011 , p. 246

${ }^{2}$ Fitri Kurniawati, "Filosofi Zakat Dalam Filantropi Islam", Adzkiya: Jurnal Hukum dan Ekonomi Syariah, Vol. 05, No. 2, September 2017, p. 233

3 Anis Tyas Kuncoro, "Zakat: Katup Pengaman Keseimbangan Kehidupan Ekonomi Umat”, Jurnal Ulul Albab: Jurnal Studi dan Penelitian Hukum Islam Vol. 1, No. 1, Oktober 2017, p. 75.

${ }^{4}$ Abdul Mannan, Teori dan Praktek Ekonomi Islam, (Jakarta: Dana Bhakti Wakaf, 2005), p. 256

5 Yoghi Citra Pratama, "Peran Zakat Dalam Penanggulangan Kemiskinan (Studi Kasus: Program Zakat Produktif Pada Badan Amil Zakat Nasional), The Journal of Tauhidinomics Vol. 1 No. 1, April 2015, p. 94
}

The idealism and normativsm of the extraordinary potential of zakat has not been "grounded" and significantly beneficial as it should be. In this case there are several obstacles that cause it, among others, first, the low level of awareness of the Muslim community towards zakat. ${ }^{6}$ Second, information about zakat that reaches the community is still relatively minimal and limited. Third, the level of public understanding of how to calculate zakat is still low, which is often related to their honesty level in calculating their zakat. Whereas fourth, public trust in zakat management organizations is still low because they are considered less professional and less transparent (accountability aspect), so that many muzakki pay or give their zakat personally and directly to the mustahiq. ${ }^{7}$

Meanwhile, according to Qardhawi, factors that can affect the success of zakat management are the expansion of the scope of compulsory zakat assets (zakat objects) which are still debatable, management that is not fully professional, and the allocation and distribution process which is not yet effective and efficient. ${ }^{8}$ Meanwhile, according to Abdurrahman Wahid, although there have been various zakat management organizations for a long time, regardless of their form and name, most of them are not yet professional and relatively more incidental and unsustainable. According to

\footnotetext{
${ }^{6}$ Anik dan Iin Emy Prastiwi, "Peran Zakat Dalam Meningkatkan Pertumbuhan Ekonomi melalui pemerataan "Equity", Proceeding Seminar Nasional \& Call For Papers The Role of Cross Cultural Program in Facing Digital Economy, STIE AAS Surakarta, 4 September 2019, p. 133

Syafe'i, Ermi Suhasti, "Mengoptimalkan Potensi Zakat", diseminarkan dalam Prosiding Simposium Nasional Ekonomi Islam (P3EI) UII, (Yogyakarta: (P3EI) UII, 2002), p. 17

8 Yusuf Qardhawi, Kiat Islam Mengentaskan Kemiskinan, (Jakarta: Gema Insani Pers, 1991), p. 16
} 
him, there are at least three main causes, namely first, the organization or institution does not yet have compelling authority. Second, the organization or institution cannot be controlled by the muzaki, directly or indirectly. Third, socio-politically there is an impression that there is a strengthening of the framework of secularism and the promotion of covert secularism which seeks to determine the religious affairs of the state. The consequence is that the aspect of zakat is considered as the authority of religion (ulama). ${ }^{?}$

From the description and some of the constraints above, it appears that the institutional factor is the most prominent and dominant. Furthermore, in this case, until now the factor of the ability of institutions or organizations managing zakat has not reached the level of service quality and management expected. One indicator is that although on the one hand the awareness of Muslims in paying zakat has shown an encouraging increase, on the other hand, on the real ground, the poor still exist, both in terms of quality and quantity. ${ }^{10}$ In order to respond to the high hopes of the Muslims for a trustworthy, transparent and professional zakat management organization, the institutional reform of the zakat management organization is very urgent. Because of its strategic role, it is time to build institutions and management of zakat funds as well as possible.

Currently, zakat management institutions are the latest form for institutions that have the power to manage zakat assets. For that reason, the ámilin in charge should have

\footnotetext{
9 Abdurrahman Wahid, Pajak Itu Zakat, (Bandung: Mizan Pustaka, 2005), p. xi-xii.

${ }^{10}$ Budi Budiman, Potensi Zakat Dana ZIS, (Yogyakarta: (P3EI) UII, 2002), p. 1
}

characteristics in accordance with Islamic values and have high professionalism, so that zakat as sets can be managed properly and on target. They must have Islamic ethics in general, such as being supportive and friendly to zakat obligators and always praying for them, be able to explain the importance of zakat in creating social solidarity and distribute zakat effectively and efficiently so that the assets of zakat are really beneficial by muzakki and so also for mustahik. ${ }^{11}$

This zakat management has been regulated by law, namely Law Number 23 Year 2011 concerning Zakat Management. In the Law of the Republic of Indonesia Number 23 of 2011 concern ing Zakat Management, it is stated that what is meant by zakat is assets that must be set aside by a Muslim or an entity owned by a Mus lim in accordance with religious provisi o ns to be given to those entitled to receive it. ${ }^{12}$

In this law there are two forms of institu t ions, first the Amil Zakat Agency (BAZ) which is formed by the government, the sec o nd the Amil Zakat Institute (LAZ) which is confirmed, fostered and protected by the government. The collection of zakat by zakat institutions is very much determined by the recognition of society, in this case how the Islamic community realizes the importance of managing zakat by a professional, trustworthy and trus tworthy institution. Public awareness and par t icipation will greatly support the collection of the huge potential of zakat. ${ }^{13}$

${ }^{11}$ Widi Nopiardo, ” Urgensi Berzakat Melalui Amil Dalam Pandangan Ilmu Ekonomi Islam”, Jurnal Ilmiah Syari'ah, Vol.15, No. 1, Juni 2016, p. 93

${ }^{12}$ Hadi Se tia Tunggal, Undang-Undang Pengelolaan Zakat dan Wakaf, (Jakarta:Fokus Media, 2000), p. 10

13 Sari Vi c iawati Machdum, "Upaya Peneguhan Eksistensi Lembaga Amil Zakat Sebagai Salah Satu Bentuk Faith Based Organization di Indonesia”, Empati: Jurnal Ilmu Kesejahteraan Sosial, Vol. 2, No. 1, Juni 2013, p. 20 
With the issuance of Law Number 23 of 2011 concern ing Zakat Management, it is hoped that zakat management institutions can play a role in managing zakat, especially for poverty alleviation and social justice. For this reason, the effectiveness of zakat management institutions is needed so that the benefits of zakat can be felt, especially to improve the standard of 1 iving of the poor. Every zakat manager is required to always improve zakat management in a better, integrated, and optimal mann e $r$ with a neat, orderly and professional management. ${ }^{14}$ Thus, zakat management in stitutions can make zakat a religious institution that has a direct functional relationship in solving social problems, such as poverty alleviation.

In reality, the achievement of the objectives of Article 3 of Law Number 23 Year 2011 concerning Zakat Management has not been maximized. Th is is because the existence of zakat is felt until now it has not been able to reduce the level of poverty, especially in the City of Lubuklinggau. Although the poverty rate has decreased based on figures from the Cen tral Statistics Agency (BPS) in 2015-2017. In 2015 it was known that there were 33.21000 or 15.6 percent, 2016 amounted to 31.01000 or 13.99 percent, while 2017 amounted to 29.54000 or 13.12 percent with a population of 226,002 people in Lubuklinggau. ${ }^{15}$

This study aims to analyze the problems faced by BA ZNAS Lubuk Linggau in realizing $t$ he effectiveness and service of zakat management as well as increasing the benefits of zakat to create welfare and poverty alleviation in the city of Lubuk Linggau. The

\footnotetext{
${ }^{14}$ Kemenag RI, Panduan Organisasi Pengelola Zakat, (Jakarta: Reva Bumat Indonesia, 2013), p. $27-29$

15 Rahman Sa ni, Sekda Kota Lubuklinggau dan Hj. Farida, Kepala Bappeda Kota Lubuklinggau
}

problems found are then used as a reference for recommen dations for solutions. In more detail, the research questions include: first, how effective are the existing zakat laws and regulations? Second, what are the problems in the Baznas Lubuk Linggau City environment related to the effectiveness of the zakat laws and regulat ions. Third, what solutions can be recommen ded for the problems faced by Baznas Lubuk Linggau City. This description will analyze the aspects of the strength of the existing zakat laws and regulations, then verify their implementation by the research subjects of Baznas Lubuk Linggau City, so that the root causes and solutions that deserve to be recommended are found.

\section{Research Method}

This type of research the researchers used empirical legal research. According to Soerjono Soekanto, empirical legal research consists of research on legal identification and effectiveness. Empirical legal research, in other words, is a type of sociological research and can also be called field research, which examines the applicable legal provisions and what happens in reality in society. In this case the author examines the efforts made by B AZNAS in alleviating poverty and the effectiveness of the implementation of Article 3 of Law Number 23 Year 2011 concerning Zakat Management at BAZNAS Lubuklinggau City.

This rese arch is descriptive qualitative. The sele ction of this type of research was carried out to obtain an overview of the efforts made by BAZNAS in overcoming poverty in Lubuk Linggau City and to find out the effectiveness of the implementation of Article 3 of Law Number 23 Year 2011 concerning Zakat Management at BAZNAS Lubuklinggau City. 
The da ta collected in this study were divid ed into three types, namely, primary data, secondary data, and tertiary data. ${ }^{16}$ Prima ry data obtained directly from the first source. Primary data in this study is information obtained directly by researchers from the object of research collected through indi vidual or group subject opinions cond ucted in BAZNAS Lubuklinggau City, as well as Article 3 of Law Number 23 Year 2011 concerning Zakat Management.

Seco ndary data used in this study are books, journals, articles, internet, and other sources that have corrections for this research. Seco ndary data provides an explanation of primary data. In other words, secondary data in this study are the opinions of several zakat mana gement figures conveyed through mass media, either through the internet or via television or other print media. Tertiary data is obtained from instructions and explanations of primary and secondary data consisting of a legal dictionary, a large Indonesian dictionary, and an encyclopedia.

Data collection techniques were observation and interviews. Observations were made by cond ucting direct observations at BAZNAS Lubuklinggau City. The interview technique carr ied out in this research was the free inte rview technique, which is an interview that is not centered, meaning that the question is $n$ ot centered on one main problem, the questions can be switched from one subject to a nother, so that the data collected can be manifold and types of nature. In this case, it is carried out on zakat managers in BAZNAS Lubu k Linggau City in order to find out thei $r$ opinion about the object, subject and

${ }^{16}$ Amirudin dan H. Zainal Asikin, Pengantar Metode Penelitian Hukum, (Jakarta: PT. Raja Grafindo Persada, Jakarta, 2004), p. 30 allocation of zakat fund distribution.

Data analysis in this study used qualitative descr iptive data, namely describing, presenting, describing or explaining all data clearly. Then the authors conclude the data induc tively, which is to draw conclusions from statements that are specific to the general in nature, so that their presentation can be understood easily.

\section{Effectiveness Assessment Factors}

The effectiveness of the implementation of Article 3 of Law Number 23 Year 2011 concerning Zakat Management at BAZNAS Lubuklinggau City is viewed from 5 factors, namely: 1) Law factors, 2) Law enforcement fac tors, 3) Facility factors, 4) Community factors, 5) Cultural factors. Based on this, the effectiveness of its implementation can only be found in statutory factors and facilities or facilities. Meanwhile, law enforcement, community and cultural factors appear to be ineffective.

\section{Law Factors}

In this case the objectives of article 3 of law Number 23 of 2011 concerning zakat ma nagement are achieved which reads: (1) increasing the effectiveness and efficiency of services in managing zakat, the indicator is an evaluation of the work program of BAZNAS ma nagement, (2) increasing the benefits of zakat to realize welfare and poverty reduction, the indicator is distribution of zakat funds more evenly so that it can reduce the level of poverty in the city of Lubuklinggau.

This can also be seen from the zakat funds c ollected by BAZNAS Lubuklinggau City in 2015-2017 as follows: in 2015 amounted to IDR 169,000,000, in 2016 amounted to IDR. 179,000,000, and in 2017 amounting 
to IDR 541,500,000. To alleviate poverty in Lubuklinggau City, the Amil Zakat Agency makes the following efforts: first, optimally empowering zakat funds through BAZNAS programs, namely the Smart Lubuk Linggau Program, Lubuk Linggau Care, Lubuk Linggu Taqwa, Healthy Lubuk Linggau, Prosperity Lubuk Linggau, and Lubuk Linggau Amil.

Emp owerment is an effort to increase the cap acity or potential of the community in economic activities in order to meet the needs of life and improve their welfare and have the potential in the national development process. ${ }^{17}$ Zak at is manifested in the form of providing revolving capital for capitalizing social projects such as building school facilities, health facilities or places of worship as well as business capital to assist the business development of traders or small entrepreneurs. ${ }^{18}$ Based on these data the aut hors analyze that zakat is able to reduce poor families, is able to reduce the poverty gap and income gap. This proves that zakat has an ext raordinary potential instrument in poverty alleviation. ${ }^{19}$

\section{Facility Factor}

Goo d facilities are an indicator of the effectiveness of organizational performance. ${ }^{20}$ The facility factor of the Lubuklinggau City B AZNAS has met the effectiveness of the implementation of Article 3 of Law Number

17 Artis, "Strategi Pengelolaan Zakat Berbasis Pe mberdayaan Masyarakat Miskin Pada Badan Amil Zakat Nasional (Baznas) Kota Pekanbaru”, Jurnal Risalah, Vol. 28, No. 2, December 2017, p. 59

18 Hamka, Standar Operasional Prosedur (SOP) Lembaga Pengelolaan Zakat, p. 68

19 F irmansyah, "Zakat As An Instrument For Poverty And Inequality Reduction”, Jurnal Ekonomi dan Pembangunan, Vol. 21, No. 2 December 2013, p. 179

${ }^{20}$ Tri Firmansyah, Achmad Supriyanto, Agus Timan, "Efek tivitas Pemanfaatan Sarana Dan Prasarana Dalam Meningkatkan Mutu Layanan”, JMSP: Jurnal Manajemen dan Supervisi Pendidikan, Vol. 2, No. 3 July 2018, p. 180
23 of 2011. This can be seen from the adequate work space of the staff. In an effort to em power zakat so that it can be carried out, what must be done is to prepare people perso nally for entrepreneurship, because in overc oming the problem of poverty is by working. By providing business coaching and training, this will be an important provision when entering the world of work.

\section{Law Enforcement Factors}

This factor has not been effective because of the lack of program supervision. BAZNAS in L ubuklinggau City does not carry out opti mal supervision, for example in the Lubu klinggau Makmur program. The lack of supervision can be explained as follows: volu nteers consisted of a coordinator and 5 members who fostered about 300 community members divided into about 20 groups. Every mont $h$ all volunteers report the training carr ied out in the Lubuklinggau Makmur prog ram to BAZNAS Lubuklinggau City. The report contains the absence of members or targets and the implementation of the program in the form of implementation dates and the number of attendees each week, as well as the title of the material given.

Bef ore being given to BAZNAS Lub uklinggau City, the coordinator made a $r$ ecapitulation of the reports made by all volunteers, both the coordinator and its members, who provided guidance in the Lubuklinggau Makmur program. The recap is attached with the volunteer report con taining all volunteer names, the date of the coaching implementation and the number of coaching carried out in a month. All volunteers, apart from providing monthly reports to BAZNAS, Lubuklinggau City, also att end the coordination meeting which is 
held if BAZNAS deems necessary, the date of the coordination meeting will be informed by telephone or sms to the volunteer coo rdinator then the volunteer coordinator will inform the members of the meeting plan. Because the coordination was not planned, the volunteers, apart from not knowing the coo rdination agenda, often did not attend the meeting. BAZNAS Lubuklinggau Cit $y$ in a coordination meeting, provides ann ouncements related to the members or targets of the Lubuklinggau Makmur program.

Sup ervision of the Lubuklinggau City National Zakat Board of programs carried out by volunteers based on the monthly reports pro vided by the volunteer coordinator and information or complaints made by volunteers in coordination meetings. The supervision carried out by BAZNAS is not optimal because it only relies on reports and information fro $m$ volunteers, without checking back or dir ectly monitoring the implementation of programs or activities that have been carried out, especially in the Lubuklinggau Makmur pro gram. ${ }^{21}$ For this reason, there is a need for strong commitment and cooperation fro $m$ various parties, especially support from the community, the Lubuklinggau city gov ernment, and no less important is the role of the Amil Zakat Board, as a whole in realizing sustainable zakat development.

\section{Community Factors}

This factor has not been effective, it can be seen from the lack of awareness of community participation in zakat. As stated by the Deputy Ch airperson of BAZNAS in Lubuklinggau

${ }^{21}$ It was stated in interviews with several volunteer members in the Lubuklinggau Sehat program on June 13, 2018
City, the main source of income is actually obtained from schools (SD-SMA) in the form of donations, while we know that the tuition fees for school children are not much. In fact, if this is done by zakat compulsors such as ASN, both structurally and functionally to sup port their zakat distribution, then zakat funds could reach billions. This is due to the lack of socialization from BAZNAS so that many people think that the zakat that must be issued is only zakat fitrah. In addition, the re is a lack of regulations from the local government governing the income zakat that employees must issue.

Imp ortant things that must be done to gen erate awareness and trust society in this zakat becomes more fertile is to give equitable kno wledge to the Islamic community about the importance of carrying out zakat to get welfare of the people while doing it obligation as a Muslim who has ordered in the Koran. Muslims are not carry out the obligation to pay zakat, because all this time they know that zakat that is obliged to be done is only zakat fitrah must be fulfilled for a moment before the Eid al-Fitr. Apart from zakat fitrah there are still a lot of zakat that can be spent by a Muslim from his property in between other than their income, from livestock, products of trade, agriculture and goo ds mine. All of them have their terms each. For that he needed zakat campaign, especially in the month of Ramadan to the Muslim community and officials government in order to raise awareness to pay zakat in the community in order can channel zakat thr ough institutions government or legal amil zakat. ${ }^{22}$

${ }^{22}$ Siti Nurhasanah and Suryani, "Maksimalisasi Potensi Zakat Melalui Peningkatan Kesadaran Masyarakat”, JEBI: Jurnal Ekonomi dan Bisnis Islam, Vol.3, No. 2 December 2018, p. 191 


\section{Cultural Factors}

This factor is still ineffective because of the way people think that zakat funds are like sustenance which is their right. Based on facts in the field most of the people are still not familiar with zakat institution. Community understanding about zakat institutions is very lacking, only partly small can understand the institution zakat, even when the researcher mentioning the word zakat institution they spontaneously said that only mosques obey they are zakat institutions. ${ }^{23}$

This problem can be seen from the addi tional capital from the institution for business development. The capital submitted by BAZNAS for community businesses has not shown a good profit. According to the expl anation above, BAZNAS Lubuklinggau City also empowers zakat funds that are prod uctive. This productive zakat fund can help alleviate poverty. Productive zakat in the form of revolving capital assistance for street vend ors. This assistance takes the form of providing loans to mustahik in a group system. The minimum number of groups is 5 people and the maximum loan is IDR 5,000,000 (five million rupiah). At the beginning of the loan, the institution only provides a loan of IDR 1,000,000 (one million rupiah), in the following year the institution will increase the am ount of the loan. The loan is interest-free an d without collateral, and the repayment system is paid in installments every month within one year.

So, the effectiveness of the implementation of Article 3 of Law Number 23 Year 2011 concerning Zakat Management at BAZNAS

${ }^{23}$ Henry Reza Novianto and Muhammad Nafik H.R., "Me ngapa Masyarakat Memilih Menunaikan Zakat Di Masjid Dibandingkan Dengan Lembaga Zakat?", JESTT, Vol. 1 No. 3 March 2014, p. 232
Lubuklinggau City can be concluded that it is not yet effective. The ineffectiveness of the implementation of this law is not only due to internal factors of BAZNAS as the zakat man agement institution, but also external fac tors, namely social and cultural factors that do not support the implementation of the law to make it more effective.

BAZ NAS's efforts in order to carry out com munity economic empowerment are to prepare people themselves to become entrepreneurs. This training or coaching from BAZNAS can be a provision for the future to become entrepreneurs. Through training, the community can understand all kinds of problems that exist. So that people get more comprehensive insight and knowledge about the business world and can foster motivation for the community. Meanwhile, the empowerment of zakat which is consumptive is zakat distributed directly to mustahik for daily consumption needs, such as the distribution of zakat mal to the poor directly by BAZNAS adm inistrators to mustahik who are in dire nee $d$, due to lack of food or experiencing disaster. This pattern is a short-term program in overcoming community problems. BAZNAS Lubuklinggau City also helps in the field of education by providing scholarships to high-achieving and underprivileged students, because parents who cannot afford to send their children to school. By providing scholarships for underprivileged children, it automatically reduces the burden on parents and at the same ti me increases their willingness to learn. So, em powerment is directed at increasing the people's economy productively, so that it can produce high added value and bigger income.

In an effort to improve the standard of living of the community, targeted empowerment pa tterns are needed, the right form is to 
provide opportunities for the poor to plan an $\mathrm{d}$ implement the development programs they have determined. The goal to be achieved from empowerment is to shape individuals an $\mathrm{d}$ communities to become independent. This independence includes independence to think, act and control what they do.

I $\mathrm{n}$ addition, the efforts being made are $m$ aking or submitting a Mayor Regulation (Perwali) on zakat. City Regional Regulation is one type of statutory regulation referred to in Article 7 paragraph (1) of Law Number 12 Year 2011 concerning the Establishment of Legislation. The purpose of the Lubuklinggau City National Amil Zakat Agency to make / propose a Mayor Regulation concerning zakat is so that the public will increase their awareness to pay zakat. The mayoral regulation also aims to increase the income of zakat funds which will be managed by BAZNAS, so that the managed funds can help reduce poverty and achieve good zakat management as expected.

\section{Conclusion}

$E$ fforts made by BAZNAS in Implementation Of Law Number 232011 to a lleviate poverty in the city of Lubuklinggau are to empower zakat funds optimally through the Smart Lubuklinggau, Lubuklinggau Peduli, L ubuklinggu Taqwa, Lubuklinggau Sehat, L ubuklinggau Makmur, and Lubuklinggau A mil Programs, and proposes Regulation of Mayor. Ideally, the efforts made by BAZNAS can be an effective solution, in order to increase t he benefits of zakat to create welfare and poverty alleviation.

The main problem that becomes an obstacle in implementing the Law is that the management institution does not yet have coercive authority, and this institution cannot be controlled by the muzakki. Apart from that, there are three indicators that show the ineffective implementation of zakat management at BAZNAS Lubuklinggau city, namely law enforcement factors, because supervision in the implementation of the planned program is not optimal; lack of awareness of public participation, because not all of them are willing to pay their zakat; and cultural factors, namely the mindset of the people who still think that the zakat fund they receive is a provision, and become their right that does not need to be accounted for.

\section{References}

Artis. "Strategi Pengelolaan Zakat Berbasis Pemberdayaan Masyarakat Miskin Pada Badan Amil Zakat Nasional (Baznas) Kota Pekanbaru". Jurnal Risalah, Vol. 28, No. 2, December 2017.

Asikin, Zainal and Amirudin. Pengantar Metode Penelitian Hukum. Jakarta: PT. Raja Grafindo Persada, Jakarta, 2004.

Budiman, Budi. Potensi Zakat Dana ZIS, Yogyakarta: P3EI UII, 2002

Faisal. "Sejarah Pengelolaan Zakat di Dunia Muslim dan Indonesia". Jurnal Analisis, Vol. XI, No. 2, December 2011.

Farida, Kepala Bappeda Kota Lubuklinggau Firmansyah, "Zakat As An Instrument For Poverty And Inequality Reduction", Jurnal Ekonomi dan Pembangunan, Vol. 21, No.

2, December 2013

Firmansyah, Tri, Achmad Supriyanto, and Agus

Timan, "Efektivitas Pemanfaatan Sarana Dan Prasarana Dalam Meningkatkan Mutu Layanan", JMSP: Jurnal Manajemen dan Supervisi Pendidikan, Vol. 2, No. 3, July 2018.

Hamka. Standar Operasional Prosedur (SOP) Lembaga Pengelolaan Zakat. Kementrian Agama RI Dirjen Masyarakat Islam 
Direktorat Pemberdayaan Zakat, 2012

Kemenag RI. Panduan Organisasi Pengelola Zakat. Jakarta: Reva Bumat Indonesia, 2013.

Kuncoro, Anis Tyas. "Zakat: Katup Pengaman Keseimbangan Kehidupan Ekonomi Umat". Jurnal Ulul Albab: Jurnal Studi dan Penelitian Hukum Islam Vol. 1, No. 1, October 2017.

Kurniawati, Fitri. "Filosofi Zakat Dalam Filantropi Islam”. Adzkiya: Jurnal Hukum dan Ekonomi Syariah, Vol. 05, No. 2 September 2017

Machdum, Sari Viciawati. " Upaya Peneguhan Eksistensi Lembaga Amil Zakat Sebagai Salah Satu Bentuk Faith Based Organization di Indonesia". Empati: Jurnal Ilmu Kesejahteraan Sosial, Vol. 2, No. 1, Juny 2013.

Mannan, Abdul. Teori dan Praktek Ekonomi Islam, Jakarta: Dana Bhakti Wakaf, 2005.

Nafik H.R, Muhammad and Henry Reza Novianto. "Mengapa Masyarakat Memilih Menunaikan Zakat Di Masjid Dibandingkan Dengan Lembaga Zakat?”. JESTT, Vol. 1 No. 3, March 2014.

Nopiardo, Widi. "Urgensi Berzakat Melalui Amil Dalam Pandangan Ilmu Ekonomi Islam”. Jurnal Ilmiah Syari'ah, Vol.15, No. 1, Juny 2016.

Pratama, Yoghi Citra. "Peran Zakat Dalam Penanggulangan Kemiskinan (Studi Kasus: Program Zakat Produktif Pada Badan Amil Zakat Nasional), The Journal of Tauhidinomics Vol. 1 No. 1 April 2015.
Prastiwi, Iin Emy and Anik. "Peran Zakat Dalam Meningkatkan Pertumbuhan Ekonomi melalui pemerataan "Equity". Proceeding Seminar Nasional \& Call For Papers The Role of Cross Cultural Program in Facing Digital Economy, STIE AAS Surakarta, 4 September 2019

Qardhawi, Yusuf. Kiat Islam Mengentaskan Kemiskinan. Jakarta: Gema Insani Pers, 1991.

Sani, Rahman, Sekda Kota Lubuklinggau

Suhasti, Ermi and Syafe'i. "Mengoptimalkan Potensi Zakat", Seminarized in Prosiding Simposium Nasional Ekonomi Islam (P3EI) UII. Yogyakarta: P3EI UII, 2002.

Sunggono, Bambang. Metode Penelitian Hukum. Jakarta: Rajawali Pers, 2011

Suryani and Siti Nurhasanah, "Maksimalisasi Potensi Zakat Melalui Peningkatan Kesadaran Masyarakat", JEBI :Jurnal Ekonomi dan Bisnis Islam, Vol.3, No. 2 December 2018

Tunggal, Hadi Setia. Undang-Undang Pengelolaan Zakat dan Wakaf. Jakarta: Fokus Media, 2010.

Wahid, Abdurrahman. Pajak Itu Zakat. Bandung: Mizan Pustaka, 2005. 